\title{
Portuguese validation of the Children's Eating Attitudes Test
}

\section{Validação portuguesa do Teste de Atitudes Alimentares para Crianças}

\author{
Maria Del Carmen Bento Teixeira ${ }^{1}$, Ana Telma Fernandes Pereira², Jorge Manuel Tavares Saraiva ${ }^{1}$, \\ Mariana Marques², Maria João Soares², Sandra Carvalho Bos², José Valente², Maria Helena Pinto de Azevedo², \\ ANTÓNIO JoÃo FerReIRA de MACEDO2
}

1 University Clinic of Paediatrics, Faculty of Medicine, University of Coimbra, Portugal.

2 Institute of Medical Psychology, Faculty of Medicine, University of Coimbra, Portugal.

Received: 2/6/2012 - Accepted: 7/11/2012

\begin{abstract}
Background: The Eating Attitudes Test (EAT) is the most widely used instrument for evaluating eating disorders in adults and adolescents in a variety of cultures and samples. Objective: The aim of this study was to analyse the psychometric properties of the Portuguese version of the Children's Eating Attitudes Test (ChEAT). Method: Nine hundred and fifty-six Portuguese secondary students ( 565 girls and 391 boys) answered the ChEAT. The test-retest reliability was obtained with data from 206 participants from the total sample who re-answered the questionnaire after 4-6 weeks. Psychometric analyses were carried out for the total sample and separately for girls and boys. Results: Internal consistency and test-retest reliability were satisfactory. Principal components factorial analysis yielded four factors in the total sample, accounting for $42.35 \%$ of the total variance. Factor structure was similar in the total sample and in both genders. Factors were labelled: F1 "Fear of Getting Fat", F2 "Restrictive and Purgative Behaviours", F3 "Food Preoccupation" and F4 "Social Pressure to Eat". The concurrent validity, explored using the Contour Drawing Figure Rating Scale (CDRS) was high. Discussion: The Portuguese version of the ChEAT is a valid and useful instrument for the evaluation of abnormal eating attitudes and behaviours among Portuguese adolescents.
\end{abstract}

Teixeira MCB, et al. / Rev Psiq Clín. 2012;39(6):189-93

Keywords: ChEAT, adolescents, eating behaviours, body dissatisfaction.

\section{Resumo}

Contexto: O Teste de Atitudes Alimentares é o instrumento mais utilizado para avaliar distúrbios alimentares em adultos e adolescentes em uma variedade de culturas e amostras. Objetivo: O objetivo deste estudo foi avaliar as propriedades psicométricas da versão portuguesa da Escala de Atitudes Alimentares para Crianças (ChEAT). Método: Novecentos e cinquenta e seis alunos do ensino secundário (565 moças e 391 moços) responderam ao ChEAT. O cálculo da fidelidade teste-reteste foi feito por meio das respostas de 206 participantes da amostra total que voltaram a responder ao questionário após quatro a seis semanas. As análises psicométricas foram realizadas para o total da amostra e para ambos os sexos separadamente. Resultados: A consistência interna e a fidelidade teste-reteste foram satisfatórias. A análise fatorial em componentes na amostra total resultou em quatro fatores que explicam $42,35 \%$ da variância total. A composição dos fatores foi semelhante na amostra total e em ambos os sexos. Os fatores denominaram-se: F1 "Medo de Engordar"; F2 "Comportamentos Restritivos e Purgativos"; F3 "Preocupação com a Comida" e F4 "Pressão Social para Comer". A validade concorrente foi explorada com a Escala de Silhuetas Corporais (CDFRS) e foi elevada. Conclusão: A versão portuguesa do ChEAT é um instrumento útil e válido para a avaliação de atitudes e comportamentos alimentares em adolescentes portugueses.

Teixeira MCB, et al. / Rev Psiq Clín. 2012;39(6):189-93

Palavras-chave: Teste Atitudes Alimentares para Crianças, adolescentes, comportamento alimentar, insatisfação corporal.

\section{Introduction}

Eating disorders (ED) are an important public health problem. The early detection and prevention of these problems are of paramount importance and priority, since they affect a considerable percentage of the adolescent population and are recently beginning to appear at earlier ages and sometimes stay through life $\mathrm{e}^{1,2}$.

The Eating Attitudes Test (EAT) is the most widely used instrument for evaluating eating disorders in adults and adolescents in a variety of cultures and samples ${ }^{3}$. In Portugal, both the long and short versions of EAT were rigorously validated and have been widely used with young adults ${ }^{4-6}$. However, a considerable shortcoming, both in clinical and research settings was, that there is not any Portuguese version for evaluating disordered eating attitudes in children and young adolescents. The aim of the present study was to analyze the psychometric properties of the ChEAT in a large sample of Portuguese young adolescents.

The ChEAT is a well-established 26-item scale designed to measure a wide range of problematic eating attitudes and behaviours among children and adolescents under 15 years old 7 . In the original study, the ChEAT showed adequate test-retest reliability ( $\mathrm{r}$
$=0.81, \mathrm{~N}=68$ ) and internal reliability (Cronbach's alpha, $\alpha=0.76$, $\mathrm{N}=316)^{7}$. Smolak and Levine also showed that the scale had an adequate internal reliability $(\alpha=0.87, \mathrm{~N}=308)$ and demonstrated moderate concurrent validity with weight management behaviour and with body dissatisfaction ${ }^{8}$. Although Maloney found that the ChEAT factor structure was quite similar to that of the EAT-267, Kelly, Thomas and Rojo-Moreno found different factor structure both in boys and in girls ${ }^{9-11}$. The objective of the present study was to analyse the psychometric properties of the ChEAT in a Portuguese adolescent sample.

\section{Method}

\section{Subjects}

Nine hundred and fifty-six adolescents 565 girls (59.0\%) and 391 boys (41\%), from four secondary schools in the urban area of Coimbra, Portugal, participated in the study. Coimbra is situated in the centre of Portugal with around 10.000 inhabitants. The schools were randomly selected; so that all social and cultural backgrounds were represented. 
The authors formed several group ages (11-13 years: $\mathrm{n}=94 ; 14-16: \mathrm{n}$ $=491 ; 17-18: \mathrm{n}=368)$; the mean age was of 15.78 years $(\mathrm{SD}=1.514)$, without statistically significant differences between ages $(\mathrm{p}=.176)$ and genders ( 565 girls $v s .391$ boys: $\mathrm{M}=15.76 \pm 1.571$ vs. $\mathrm{M}=15.82$ $\pm 1.431, \mathrm{p}=.567)$. Mean Body Mass Index (BMI) was of $20.69 \mathrm{~kg} /$ (Height $)^{2}(\mathrm{SD}=2.662)$ for the total sample, being significantly lower in girls $(\mathrm{M}=20.42 \pm 2.745$ vs. $\mathrm{M}=21.07 \pm 2.486, \mathrm{p}<.001)$.

\section{Measures}

Children Eating Attitudes Test (ChEAT)7. The Children Eating Attitudes Test is a 26 items scale. Each item is rated in a Likert scale from 1 (never) to 6 (always). The most symptomatic response is recoded into a score of 3 ("always"), the next to 2 ("usually") and the next to 1 ("often"). The remaining choices ("sometimes", "rarely" and "never") receive a score of 0 . Therefore, ChEAT scores can range from 0 to 78 , with higher scores indicating more eating behaviours disturbance. In the original version, the item 19 is negatively correlated with the rest of the survey.

The original version was translated into Portuguese by the research group. Back translation was done by a bilingual psychiatrist and a total overlap with the English original version was found. Preliminary qualitative item analysis included the thinking aloud methodology with pilot participants (affected and non-affected girls) and experts panels.

Contour Drawing Figure Rating Scale (CDFRS; Thompson \& Gray, 1995) ${ }^{12}$. The Contour Drawing Figure Rating Scale consists of nine male and nine female figures, ranging from thin to obese in increasing increments; the new CDFRS has demonstrated adequate psychometric properties ${ }^{12}$. For the purpose of this study, participants were asked to identify the figure that represents their current body size and their ideal body size. The answers scale can range from 1 (smallest figure) to 9 (largest figure).

\section{Procedure}

This study is part of a larger study concerning the perfectionism, self esteem, body image and eating disorders prevention in adolescents which data were collected in 2010. Permission was obtained from the Ethic Commission of Faculty of Medicine of Coimbra, from the Portuguese Data Protection Authority and from the schools' headmasters. The voluntary nature and general format of the research were explained and informed consent was also obtained from the parents of the adolescents who took part. Confidentiality was ensured following the guidelines of the Portuguese law for data protection (Law 67/98; 26 October). All students returned the questionnaires. To study the temporal stability 206 respondents $(124,60.2 \%$ girls and $82,39.8 \%$ boys) answered the questionnaires in two different moments separated by approximately four-six weeks. The ChEAT concurrent validity was explored using the CDFRS as a criterion.

\section{Results}

\section{Factor analysis}

The 26 items of the ChEAT were subjected to a principal components analysis. The suitability of the data for factor analysis was assessed. The Kaiser-Meyer-Oklin value was .835, exceeding the recommended Kaiser's value of .600 and Barlett's Test of Sphericity reached statistical significance $(\mathrm{p}<.001)$, supporting the factorability of the correlation matrix ${ }^{13,14}$.

Principal components analysis revealed the presence of six components with eigenvalues exceeding 1, explaining $51.89 \%$ of the total variance. An inspection of the Cattel's Scree plot and also of the item's content/interpretability led us to select a four factors structure that explained $42.40 \%$ of the variance (Table 1). The Cattel's Scree plot and also the item's content were quite similar in girls and boys.

Only slight differences in factors composition were found between genders and the whole sample (Table 1). In both genders, Factor 1 was labelled "Fear of Getting Fat", because its items describe the intense fear and preoccupation of getting fat and being overweight. The second factor was labelled "Restrictive and Purging Behaviours", as it includes items like "I vomit after eating" (9), "I stay away from foods with sugar in them" (16), "I eat diet foods" (17). The third factor was labelled "Food Preoccupation", as it relates to thoughts about food, loss of control over eating and bulimic behaviours. The fourth factor, "Social Pressure to Eat", is composed of 3 items that describe a perceived pressure from others to eat and gain weight. The factor's Cronbach $a$ were acceptable considering the number of items (Table 1).

\section{Internal reliability}

For the whole sample, internal consistency coefficient ( $\alpha$ ) was .727. For the girls it was .755 and for the boys it was .644.

Pearson correlation coefficients between each item and the total score (excluding the item) ranged from .610 (item 14) to .056 (item 19) and 9 items $(3,4,5,9,13,15,19,25$ and 26) could not be considered "good", as their Pearson's correlation coefficients with the corrected total were $\leq .20$; only two out of these items ( 4 and 13) had the effect of decreasing the Cronbach alpha if excluded. In general, for the girls and the boys sub samples, the Pearson correlation coefficients between each item and the total were higher than for the total sample. Because the correlations between the items 19 and 25 were negative with the corrected total, both items were reversed scored. When these 2 items were reversed, the Cronbach's alpha, ascended to .771 (total sample), .790 (girls) and .652 (boys).

\section{Test-retest reliability}

Temporal stability was analysed by the test-retest correlation method (Pearson correlation). For the total sample the correlation was of $0.602(n=206)$. The correlation for girls $(r=0.612 ; n=123)$ was higher than for boys $(\mathrm{r}=0.569 ; \mathrm{n}=83)$. Total mean scores between test and re-test were not statistically significant in the total sample $[\mathrm{M}=7.87 \pm 5.596$ vs. $\mathrm{M}=7.59 \pm 6.204 ; \mathrm{t}(206)=.737 ; \mathrm{p}=.462]$, in the girls sub-sample $[\mathrm{M}=8.57 \pm 6.021$ vs. $\mathrm{M}=7.97 \pm 6.754$; $\mathrm{t}$ (123) $=1.172 ; \mathrm{p}=.243]$, and in the boys sub-sample $[\mathrm{M}=6.80 \pm 4.723$ vs. $\mathrm{M}=7.02 \pm 5.254 ; \mathrm{t}(81)=-.427 ; \mathrm{p}=.670]$.

\section{ChEAT scores}

The mean ChEAT score in our sample was of $8.61(\mathrm{SD}=7.03)$. It was significantly higher in girls than in boys $[\mathrm{M}=9.44 \pm 7.212$ vs. $\mathrm{M}=$ $7.28 \pm 5.126 ; \mathrm{t}(946,873)=5,397 ; \mathrm{p}<.001]$. Mean differences between age groups (11-13 vs. 14-16 vs. 17-18 years) were not statistically different $[\mathrm{M}=9.77 \pm 7.205$ vs. $8.32 \pm 7.163$ vs. $8.70 \pm 6.806$; F (2, $950)=1.739, \mathrm{p}=.176]$.

The cut off score of our experimental version was selected using the $M+1 S D$ criteria, which corresponded to 16 for the total sample, 17 for the girls sub-sample and 12 for the boys sub-sample. $13.49 \%$ (n $=129)$ of the total sample, $19.10 \%(n=108)$ of the girls and $11.60 \%$ $(n=45)$ of the boys scored above these cut-offs.

\section{Concurrent validity (CDFRS)}

In the total sample, the mean ratings for the current body size was of $5.11(\mathrm{SD}=1.320)$ and the mean rating for ideal body size was of 4.61 $(\mathrm{SD}=1.126)$, which were statistically different $[\mathrm{t}(951)=12.333 ; \mathrm{p}<$ $.001]$. For girls, these respective values were of $4.89(\mathrm{SD}=1.44)$ and of $4.10(\mathrm{SD}=1.09)$ and the difference was also statistically significant $[\mathrm{t}$ $(160)=14.190 ; \mathrm{p}<.001]$. For the boys, the difference between the current body size $(M=5.34 ; S D=.69)$ and the ideal body size $(M=5.43$; $\mathrm{SD}=1.03)$ was not statistically significant $[\mathrm{t}(390)=1.792, \mathrm{p}=.086]$.

In the total sample, the mean degree of satisfaction with body size (difference between the ideal body size and the current body size) was of $-.50(\mathrm{SD}=1.24)$. The mean degree of satisfaction was significantly higher in girls than in boys $[-.78 \pm 1.306 v s-.08 \pm 1.027$; $\mathrm{t}(936.150)=-9.145, \mathrm{p}<.001]$. 
Table 1. ChEAT factor structure

\begin{tabular}{|c|c|c|c|}
\hline & \multicolumn{3}{|c|}{ Loadings } \\
\hline & $\begin{array}{l}\text { Total sample } \\
\qquad(\mathrm{N}=956)\end{array}$ & $\begin{array}{c}\text { Girls } \\
(\mathrm{N}=565)\end{array}$ & $\begin{array}{c}\text { Boys } \\
(\mathrm{N}=391)\end{array}$ \\
\hline \multicolumn{4}{|l|}{ Factor 1 - Fear of getting fat } \\
\hline 11 - I think a lot about wanting to be thinner & .848 & .853 & .759 \\
\hline 14 - I think a lot about having fat on my body & .835 & .852 & .748 \\
\hline 1 - I am scared about being overweight & .712 & .709 & .560 \\
\hline 12 - I think about burning up energy when I exercise & .680 & .736 & .525 \\
\hline 22 - I feel uncomfortable after eating sweets & .579 & .596 & -- \\
\hline 23 - I have been dieting & .546 & .610 & -- \\
\hline 10 - I feel guilty after eating & .408 & .461 & -- \\
\hline 2 - I stay away from eating when I am hungry & .376 & .423 & $<.30$ \\
\hline 24 - I like my stomach to be empty & .335 & -- & .543 \\
\hline \multirow[t]{2}{*}{25 - I enjoy trying new rich foods } & .308 & $<.30$ & $<.30$ \\
\hline & $E V=15,32 \% ; \alpha=.791$ & $\mathrm{EV}=16.80 \% ; \alpha=.849$ & $\mathrm{EV}=10.81 \% ; \alpha=.667$ \\
\hline \multicolumn{4}{|l|}{ Factor 2 - Restrictive and purging behaviours } \\
\hline 7 - I try to stay away from foods such as breads, potatoes, and rice & 649 & .624 & .406 \\
\hline 16 - I stay away from foods with sugars in them & .628 & .568 & .395 \\
\hline 17 - I eat diet foods & .584 & .602 & .484 \\
\hline 6 - I am aware of the energy (calorie) content in foods that I eat & .539 & .453 & .579 \\
\hline 9 - I vomit after I have eaten & .387 & .399 & .578 \\
\hline \multirow[t]{6}{*}{5 - I cut my food into small pieces } & .340 & .425 & $<.30$ \\
\hline & & .467 (item 24) & \\
\hline & & & .664 (item 10) \\
\hline & & & .655 (item 23) \\
\hline & & & .468 (item 22) \\
\hline & $E V=10,14 \% ; \alpha=.575$ & $\mathrm{EV}=10.34 \% ; \alpha=.640$ & $E V=10.18 \% ; \alpha=.673$ \\
\hline \multicolumn{4}{|l|}{ Factor 3 - Food preoccupation } \\
\hline 3 - I think about food a lot of the time & .750 & .737 & .718 \\
\hline 21 - I give too much time and thought to food & .725 & .637 & .759 \\
\hline 4 - I have gone on eating binges where I feel that I might not be able to stop & .668 & .622 & .687 \\
\hline 18 - I think that food controls my life & .532 & .486 & .553 \\
\hline \multirow[t]{4}{*}{19 - I can show self-control around food } & .342 & .380 & .370 \\
\hline & & .374 (item 26) & \\
\hline & & & .394 (item 15) \\
\hline & $\mathrm{EV}=9,13 \% ; \alpha=.511$ & $\mathrm{EV}=8.67 \% ; \alpha=.465$ & $E V=10.08 \% ; \alpha=.573$ \\
\hline \multicolumn{4}{|l|}{ Factor 4 - Social pressure to eat } \\
\hline 20 - I feel that others pressure me to eat & .801 & .806 & .822 \\
\hline 8 - I feel that others would like me to eat more & .787 & .819 & .676 \\
\hline \multirow[t]{3}{*}{13 - Other people think I am too thin } & .747 & .779 & .502 \\
\hline & & & .530 (item 26) \\
\hline & $\mathrm{EV}=7,75 \% ; \alpha=.707$ & $\mathrm{EV}=8.24 \% ; \alpha=.745$ & $E V=7.65 \% ; \alpha=.572$ \\
\hline \multicolumn{4}{|l|}{ Factors deleted } \\
\hline 15 - I take longer than others to eat my meals & $<.30$ & $<.30$ & \\
\hline 26 - I have the urge to vomit after eating & $<.30$ & & \\
\hline 25 - I enjoy trying new rich foods & & $<.30$ & $<.30$ \\
\hline
\end{tabular}

EV: explained variance; $\alpha$ : Cronbach alpha.

The body dissatisfaction was significantly and negatively correlated with the total ChEAT, F1 (Fear of Getting Fat), F2 (Restrictive and Purging Behaviours) and F3 (Food Preoccupation) and significantly and positively correlated with F4 (Social Pressure to Eat) in the total sample. In the boys and girls sub-samples, only F3 (Food Preoccupation) was not significantly correlated with body dissatisfaction.

The differences in eating behaviour dimensions between groups with distinct body satisfaction levels were also analyzed. Based on body satisfaction levels, participants were distributed in three groups as follows: Group 1: Want to be thinner (negative scores between current body size and ideal body size); Group 0: Satisfied (no differences between current body size and ideal body size); Group 1: Want to be fatter (positive scores between current body size and ideal body size). Mean differences between groups are depicted in table 3 .

In the total sample, significant mean differences were found between the three body satisfaction groups and all eating behaviour dimensions mean scores, except for F3 (Food Preoccupation). In relation to the Fear of Getting Fat (F1), Restrictive and Purgative Behaviours (F2) and the total ChEAT mean scores, it was found a significantly decrease through the body satisfaction groups, from $-1,0$ to 1 . Concerning the Social Pressure to Eat (F4) mean scores, there were a significantly increase between body satisfaction groups -1 and 1 , but not between groups -1 vs. 0 groups. In the girls and 
boys sub-samples significant mean differences were found between the three body satisfaction groups in all eating behaviour dimensions scores, except for F3. The pattern of F1, F2 and F4 mean scores between groups were similar (decreasing significantly through the body satisfaction groups $-1,0$ and 1 for F1 and F2 and increasing for F4) (Table 3).

Table 2. Pearson correlation between body satisfaction and ChEAT

\begin{tabular}{|c|c|c|c|c|c|c|}
\hline & \multicolumn{2}{|c|}{ Total sample } & \multicolumn{2}{|c|}{ Girls } & \multicolumn{2}{|c|}{ Boys } \\
\hline $\begin{array}{l} \pm \text { Body disatisfaction } \\
\text { ChEAT }\end{array}$ & $r$ & $\mathrm{p}$ & $r$ & $\mathrm{p}$ & $r$ & $p$ \\
\hline $\begin{array}{l}\text { Factor } 1 \\
\text { Fear of getting fat }\end{array}$ &,- 491 & $<.001$ &,- 468 & $<.001$ &,- 377 & $<.001$ \\
\hline $\begin{array}{l}\text { Factor } 2 \\
\text { Restrictive and purging behaviours }\end{array}$ &,- 230 & $<.001$ &,- 231 & $<.001$ &,- 207 & $<.001$ \\
\hline $\begin{array}{l}\text { Factor } 3 \\
\text { Food preoccupation }\end{array}$ &,- 077 & .018 &,- 078 & $.064 \mathrm{NS}$ &,- 070 & $.168^{\mathrm{NS}}$ \\
\hline $\begin{array}{l}\text { Factor } 4 \\
\text { Social pressure to eat }\end{array}$ & .190 & $<.001$ & ,262 & $<.001$ & ,117 & .021 \\
\hline Total ChEAT & -.376 & $<.001$ & -.348 & $<.001$ &,- 283 & $<.001$ \\
\hline
\end{tabular}

r: Pearson correlation coefficient; NS: no significant.

Table 3. ChEAT scores (mean \pm SD) by body satisfaction groups (total sample, girls and boys)

\begin{tabular}{|c|c|c|c|c|c|c|}
\hline \multirow{3}{*}{ ChEAT } & \multicolumn{5}{|c|}{ Body satisfaction/dissatisfaction } & \multirow{3}{*}{ PostHoc** } \\
\hline & $\begin{array}{c}(-1) \text { Want to be } \\
\text { thinner } \\
(n=426) \\
\text { T: IMC: } 21.98 \pm 2.788 \\
\text { G: IMC: }: 21.65 \pm 2.769 \\
\text { B: IMC:22.95 } 2.626\end{array}$ & $\begin{array}{c}\begin{array}{c}\text { Satisfied } \\
(\mathrm{n}=379)\end{array} \\
\text { T: IMC: } 19.96 \pm 2.046 \\
\text { G: IMC: } 19.05 \pm 1.751 \\
\text { B: IMC:20.89 } 1.907\end{array}$ & $\begin{array}{l}\text { Want to be fatter } \\
\quad(n=147) \\
\text { T: IMC: } 18.77 \pm 1.739 \\
\text { G: IMC: } 18.03 \pm 1.499 \\
\text { B: IMC: } 19.22 \pm 1.727\end{array}$ & \multicolumn{2}{|c|}{ One-Way ANOVA } & \\
\hline & $\mathrm{M} \pm \mathrm{DP}$ & $\mathrm{M} \pm \mathrm{DP}$ & $\mathrm{M} \pm \mathrm{DP}$ & $\mathrm{F}$ & $p$ & \\
\hline $\begin{array}{l}\text { Factor } 1 \\
\text { Fear of getting fat } \alpha\end{array}$ & $\begin{array}{l}\text { T: } 6.43 \pm 5.552 \\
\text { G: } 5.12 \pm 5.272 \\
\text { B: } 2.60 \pm 3.043 \\
\end{array}$ & $\begin{array}{c}\text { T: } 2.37 \pm 2.798 \\
\text { G: } 1.53 \pm 2.775 \\
\text { B: } .60 \pm 1.302 \\
\end{array}$ & $\begin{array}{l}\text { T: } 1.83 \pm 2.164 \\
\text { G: } 67 \pm 1.876 \\
\text { B: } .62 \pm 1.420 \\
\end{array}$ & $\begin{array}{l}\text { T: } 118.488 \\
\text { G: } 53.695 \\
\text { B: } 39.889\end{array}$ & $\begin{array}{l}\mathrm{T}:<.001 \\
\mathrm{G}:<.001 \\
\mathrm{~B}:<.001 \\
\end{array}$ & $\begin{array}{l}\mathrm{T}:-1>0^{* *}, 1^{* *} \\
\mathrm{G}:-1>0^{* *}, 1^{* *} \\
\text { B: }-1>0^{* *}, 1^{* *}\end{array}$ \\
\hline $\begin{array}{l}\text { Factor } 2 \\
\text { Restrictive and purging } \\
\text { behaviours }{ }^{\alpha}\end{array}$ & $\begin{array}{l}\text { T: } 1.90 \pm 2.556 \\
\text { G: } 2.24 \pm 2.950 \\
\text { B: } 1.32 \pm 2.317\end{array}$ & $\begin{array}{c}\text { T: } 1.21 \pm 1.731 \\
\text { G: } 1.38 \pm 1.844 \\
\text { B: } .73 \pm 1.857\end{array}$ & $\begin{array}{l}\text { T: } .55 \pm 1.044 \\
\text { G: } .60 \pm 1.116 \\
\text { B: } .30 \pm .767\end{array}$ & $\begin{array}{c}\text { T: } 25.945 \\
\text { G: } 14.012 \\
\text { B: } 8.073\end{array}$ & $\begin{array}{l}\mathrm{T}:<.001 \\
\mathrm{G}:<.001 \\
\mathrm{~B}:<.001\end{array}$ & $\begin{array}{c}\mathrm{T}:-1>0^{* *}, 1^{* *} \\
0>1^{* *} \\
\text { G: }-1>0^{* *}, 1^{* *} ; 0>1^{*} \\
\text { B: }-1>0^{*}, 1^{* *}\end{array}$ \\
\hline $\begin{array}{l}\text { Factor } 3 \\
\text { Food preoccupation } \beta\end{array}$ & $\begin{array}{l}\text { T: } 2.40 \pm 2.172 \\
\text { G: } 2.35 \pm 2.002 \\
\text { B: } 2.83 \pm 3.118 \\
\end{array}$ & $\begin{array}{l}\text { T: } 2.13 \pm 1.953 \\
\text { G: } 2.03 \pm 1.729 \\
\text { B: } 2.46 \pm 2.364 \\
\end{array}$ & $\begin{array}{l}\text { T: } 2.26 \pm 2.163 \\
\text { G: } 2.76 \pm 2.277 \\
\text { B: } 2.23 \pm 2.124 \\
\end{array}$ & $\begin{array}{l}\mathrm{T}: 1.783 \\
\mathrm{G}: 3.542 \\
\mathrm{~B}: 1.418\end{array}$ & $\begin{array}{c}\text { T: .169ns } \\
\text { G:.03 } \\
\text { B:. .243ns }\end{array}$ & \begin{tabular}{|l|}
- \\
-- \\
-- \\
\end{tabular} \\
\hline $\begin{array}{l}\text { Factor } 4 \\
\text { Social pressure to eat } \alpha\end{array}$ & $\begin{array}{l}\text { T: } .35 \pm 1.081 \\
\text { G: } .33 \pm 1.023 \\
\text { B: } .43 \pm 1.272\end{array}$ & $\begin{array}{c}\text { T: } .40 \pm 1.130 \\
\text { G: } .64 \pm 1.458 \\
\text { B: } .18 \pm .699 \\
\end{array}$ & $\begin{array}{c}\text { T: } 1.25 \pm 2.084 \\
\text { G: } 2.04 \pm 2.472 \\
\text { B: .78 } 1.652\end{array}$ & $\begin{array}{c}\mathrm{T}: 28.246 \\
\mathrm{G}: 35.982 \\
\mathrm{~B}: 8.434\end{array}$ & $\begin{array}{l}\mathrm{T}:<.001 \\
\mathrm{G}:<.001 \\
\mathrm{~B}:<.001\end{array}$ & $\begin{array}{c}\text { T: }-1<1^{* *} ; 0<1^{* *} \\
\text { G: }-1<0^{*}, 1^{* *} ; 0<1^{* *} \\
\text { B: }-1<1^{*} ; 0<1^{* *}\end{array}$ \\
\hline Total & $\begin{array}{c}\text { T: } 11.40 \pm 8.264 \\
\text { G: } 12.22 \pm 8.622 \\
\text { B: } 9.01 \pm 6.612\end{array}$ & $\begin{array}{l}\text { T: } 6.45 \pm 4.998 \\
\text { G: } 7.27 \pm 5.387 \\
\text { B: } 5.62 \pm 4.429 \\
\end{array}$ & $\begin{array}{l}\mathrm{T}: 6.198 \pm 4.338 \\
\text { G: } 7.96 \pm 4.690 \\
\text { B: } 5.13 \pm 3.751\end{array}$ & $\begin{array}{l}\mathrm{T}: 44.595 \\
\mathrm{G}: 29.582 \\
\mathrm{~B}: 20.035\end{array}$ & $\begin{array}{l}\mathrm{T}:<.001 \\
\mathrm{G}:<.001 \\
\mathrm{~B}:<.001\end{array}$ & $\begin{array}{l}\text { T: }-1>0^{* *}, 1^{* *} \\
\text { G: }-1>0^{* *}, 1^{* *} \\
\text { B: }-1>0^{* *}, 1^{* *}\end{array}$ \\
\hline
\end{tabular}

T: total sample; G: girls; B: boys; " $p<.001 ; "$ $p<.01 ; \alpha$ LSD; $\beta$ Tamhane; NS: no significant.

\section{Discussion}

This study presents the validation of the ChEAT questionnaire in a large representative sample of Portuguese young adolescents. Internal reliability, construct and concurrent validity, and scores distribution were examined. Although the Maloney et al. original ChEAT version recommended 25 items, we examined the 26 item version, reversing items 19 and 25 . As other authors did, the factor structures and all the psychometrics were separately analysed in boys and girls sub samples ${ }^{9,10}$.

The Portuguese ChEAT psychometric properties are good. The four factors account for $42.40 \%$ of the total variance. The number of factors and their composition in both genders, were nearly identical to that obtained for other authors $7,8,15$.

The internal reliability $(\alpha=.73)$ and the test-retest reliability coefficient $(\alpha=.602)$ were lower that of the original version ${ }^{7,8}$, but slightly higher than the reported in the ChEAT Spanish version ${ }^{16}$.

In general, our mean score values were lower than the figures reported by other researches, but the ChEAT mean score was also significantly higher in girls than in boys ${ }^{11}$. As our cut-off scores was based on the mean and SD, different cut-off values were computed for girls and boys. Results showed that using the same cut-off for both genders can be risky, particularly for boys.

Concurrent validity was assessed by examining the correlations between ChEAT and CDFRS scores. The experts in psychometrics point out that one of the best external criterion to validate a questionnaire intended to assess psychiatric symptomatology is to compare the scores of two or more different groups of people on a specific scale and analyze if the direction of the difference is the expected ${ }^{17}$.

In fact, this was what we found using the group criteria based on CDFRS: total and dimensional scores of the ChEAT were significantly higher in the participants who want to be thinner, in both genders. Consistent with previous studies, the findings from the present study suggest that body dissatisfaction is related to eating problems among adolescents and adults ${ }^{18-22}$. Specifically, our study showed that adolescents who wanted to be thinner, mainly girls, but also boys, engaged more in dieting behaviors. 
It is of note that this is not the unique Portuguese version of the ChEAT. In fact, Barillari et al. ${ }^{23}$, recently published a preliminary transcultural adaptation of the ChEAT, including the translation to Portuguese from Brazil, and also the back translation, technical review and semantic evaluation. In spite of the expected slightly idiomatic differences between the item content of these two versions, the two versions are quite similar. At the present moment it is not yet possible to compare the psychometric properties between these to Portuguese versions, because the study from Brazil $^{23}$ does not include the reliability and the validity quantitative analysis.

In conclusion, the Portuguese version of the ChEAT is an adequate and valid instrument for measuring disturbed eating attitudes and behaviors in Portuguese adolescents.

\section{References}

1. Klump KL, Bulik CM, Kaye WH, Treasure J, Tyson E. Academy for eating disorders position paper: eating disorders are serious mental illnesses. Int J Eat Disord. 2009;42(2):97-103.

2. Araújo MX, Henriques MIRS. Que "diferença faz a diferença" na recuperação da anorexia nervosa? Rev Psiq Clín. 2011;38(2):71-6.

3. Garfinkel PE, Newman A. The Eating Attitudes Test: twenty-five years later. Eat Weight Disord. 2001;6:1-24.

4. Pereira AT, Maia B, Bos S, Soares MJ, Cabral AS, Macedo A, et al. The Portuguese short form of the Eating Attitudes Test-40. Eur Eat Disord Rev. 2008;16:319-25.

5. Macedo A, Soares MJ, Azevedo MH, Gomes A, Pereira AT, Maia B, et al. Perfectionism and eating attitudes in Portuguese university students. Eur Eat Disord Rev. 2007;15(4):296-304.

6. Bento C, Saraiva J, Pereira AT, Azevedo MH, Macedo A. Atitudes e comportamentos alimentares em uma população adolescente portuguesa. Pediatria (São Paulo). 2011;33(1):21-8.

7. Maloney MJ, McGuire JB, Daniels SR. Reliability testing of a children's version of The Eating Attitudes Test. Child Adolesc Psych. 1988;27:541-3.

8. Smolak L, Levine MP. Psychometric properties of the children's version of Eating Attitudes Test. Int J Eat Disord. 1994;3:275-82.
9. Kelly C, Riccardelli LA, Clarke JD. Problem eating attitudes and behaviors in young children. Int J Eat Disord. 1999;25:281-6.

10. Thomas K, Ricardelli LA, Williams R. Gender traits and self-concept as indicators of eating and body dissatisfaction among Children. Sex Roles. 2000;43(7/8).

11. Rojo-Moreno L, García-Miralles I, Plumed J, Barberá M, Morales MM, Ruiz E, et al. Children's Eating Attitudes Test: validation in the sample of Spanish schoolchildren. Int J Eat Disord. 2011;44(6):540-6.

12. Thompson MA, Gray JJ. Development and validation of a new body image assessment tool. J Pers Assess. 1995;64:258-69.

13. Kaiser HF. An index of factorial simplicity. Psychometrika. 1974;39:31-6.

14. Barlett MS. A note on the multiplying factors for various $\chi^{2}$ approximation. J Roy Statist Soc Ser B. 1954;16:296-8.

15. Maloney MJ, McGuire JB, Daniels SR, Specker B. Dieting behavior and eating attitudes in children. Pediatrics. 1989;84(3):482-9.

16. Sancho C, Asorey O, Arija V, Canals J. Psychometric characteristics of the children's eating attitudes test in a Spanish sample. Eur Eat Disord Rev. 2005;13;338-43.

17. Anastasi A, Urbina S. Testagem psicológica. $7^{\mathrm{a}}$ ed. Porto Alegre: Artmed; 2000.

18. Rolland K, Farnell D, Griffiths RA. Body figure perceptions and eating attitudes among Australian schoolchildren aged 8-12 years. Int J Eat Disord. 1997;21:273-8.

19. Shur EA, Sanders M, Steiner H. Body dissatisfaction and dieting in young children. Int J Eat Disord. 2000;27:74-82.

20. Erickson SJ, Gerstle, M. Developmental considerations in measuring children's disordered eating attitudes and behaviors. Eat Behav. 2007;8:224-35.

21. Latzer Y, Witztum E, Stein D. Eating disorders and disordered eating in Israel: an updated review. Eur Eat Disord Rev. 2008;16:361-74.

22. Timerman F, Scagliusi F, Cordás T. Acompanhamento da evolucão dos distúrbios de imagem corporal em pacientes com bulimia nervosa, ao longo do tratamento multiprofissional. Rev Psiq Clín. 2010;37(3):113-7.

23. Barillari ML, Teixeira PC, Hearst N, Kotait M, Cordas TA, Conti MA. Adaptação transcultural preliminar do Children's Eating Attitude Test (Cheat) para o idioma português. Rev Bras Saúde Matern Infant. 2011;11(4):437-44. 